\title{
TEACHING READING THROUGH RECIPROCAL TEACHING METHOD
}

\author{
${ }^{1}$ Beny Hamdani* \\ Universitas Islam Zainul Hasan, Indonesia \\ *Corresponding Author: benyhamdani.ielts9.consultation@gmail.com
}

\begin{abstract}
This paper aims to investigate whether the university students who are taught reading through Reciprocal Teaching Method achieve better in reading ability than those who are taught through Direct Reading Thinking Activities. The design of this study is a quasi-experimental, non-randomized control group, pretest-posttest since it is conducted in a classroom setting that the subjects have been organized into classes. The subject of the study was the fourth term of university students of English education study program consisting 30 university students. The instrument of this research was a test as Pre-test and Post-test in the form of reading comprehension questions. The data analysis used Independent T-Test. Based on the result of the calculation of post-test from experimental and control groups, the alternative hypothesis ( $\mathrm{Ha}$ ) was accepted. The result of the study shows that the use of the Reciprocal Teaching Method can improve the university students' reading ability. It proves the hypothesis of the study that students who are taught reading through the Reciprocal Teaching method achieve better in reading ability than those who are taught through Direct Reading Thinking Activities. Based on this result, it can be concluded that the Reciprocal Teaching Method can be used as an alternative method to teach reading, so that the students are able to understand the texts comprehensively. It also makes the university students more active in the teaching learning process and can improve their ability as well.
\end{abstract}

Keywords: Effectiveness; Reading Comprehension; Reciprocal Teaching Method

\begin{abstract}
ABSTRAK
Penelitian ini bertujuan untuk menyelidiki apakah mahasiswa yang diajar membaca melalui Metode Mengajar resiprokal mencapai kemampuan membaca yang lebih baik daripada mereka yang diajar melalui Kegiatan Berpikir Membaca Langsung. Desain penelitian ini adalah quasi-eksperimental, kelompok kontrol non-acak, pretest-posttest karena dilakukan dalam pengaturan ruang kelas bahwa subjek telah diatur dalam kelas. Subjek penelitian adalah semester empat mahasiswa program studi pendidikan bahasa Inggris yang terdiri dari 30 mahasiswa. Instrumen penelitian ini adalah tes sebagai Pretest dan Post-test dalam bentuk pertanyaan pemahaman bacaan. Analisis data menggunakan Independent T-Test. Berdasarkan hasil perhitungan post-test dari kelompok eksperimen dan kontrol, hipotesis alternatif (Ha) diterima. Hasil penelitian menunjukkan bahwa penggunaan Metode Pengajaran Resiprokal dapat meningkatkan kemampuan membaca mahasiswa. Ini membuktikan hipotesis penelitian bahwa siswa yang diajar membaca melalui metode Mengajar resiprokal mencapai kemampuan membaca yang lebih baik daripada mereka yang diajar melalui Kegiatan Berpikir Membaca Langsung. Berdasarkan hasil ini, dapat disimpulkan bahwa Metode Pengajaran Resiprokal dapat digunakan sebagai metode alternatif untuk mengajar membaca, sehingga siswa dapat memahami teks secara komprehensif. Ini juga membuat para mahasiswa lebih aktif dalam proses belajar mengajar dan dapat meningkatkan kemampuan mereka juga.
\end{abstract}


Hamdani, B. (2020). Teaching Reading through Reciprocal Teaching Method. Celtic: A Journal of Culture, English Language Teaching, Literature, \& Linguistics, 7(1), 23-34.

Kata Kunci: Efektivitas; Pemahaman Membaca; Metode Pengajaran Resiprokal

\section{INTRODUCTION}

Since the 4.0.industry revolution in which people are able to get information perfectly throughout the world, people need a mean of international communication much more than it used to be. That is the reason why English as a lingua franca plays an important role. Its role can be seen in almost every field including education.

Comprehending English means acquiring such four basic skills of language, one of which is reading. Reading is a stepping stone to be success, not only in education but also in everyday life (Diah R W and Kurniasih, 2018:01). Moreover, reading is a thinking process in order to recognize words require interpretation of graphic symbols (Roe, 2012:34) . It is an activity of understanding written texts. By reading, the university students are able to access any information they need to support their study. It is supported by Anderson (1999) that reading is the most important skill to be learnt by students because by reading they can get greater progress and attain greater development in all academic areas. To comprehend a reading selection thoroughly, a person must be able to use the information to make conclusion and read critically and creatively to understand the figurative language, determine the authors' purpose, evaluate the ideas presented, and apply the ideas to actual situation. All of the skills involve thinking process.

Furthermore, Hedgcock and Ferris (2009:49) states that reading is a complex interaction of cognitive processes and strategies used by the reader and various types of information contained in the text. In that process, the readers integrate their existing knowledge with the information containing in the text and context of the reading situation. In other word, reading is an interaction between knowledge and experiences of an individual reader and the characteristics of a given text (Hedgock and Ferris, 2009:73)

Next, Sulistyo (2011:20) states that the process of uncovering the writer's message in the written text is commonly called reading. Based on the statement above, Directed reading thinking activities and reciprocal teaching method were chosen as methods which is going to be investigated in this research. In other words, reading is also an interactive process that connects the reader and the text, resulting in comprehension (Saraswati Ayudiah and Sumarsono P ,2014:02)

Directed Reading Thinking Activities (DRTA) was developed by Stauffer in 1969. Directed Reading Thinking Activities is a method that guides students in asking questions about a text, making predictions, and then reading to confirm or refute their prediction.

There are some phases of application of directed reading thinking method that should be implemented for teaching reading. As the first phase of directed reading thinking method is the pre reading phase. It focuses on the instruction of the topic to be discussed. In this case, the teacher concerns building a rich conceptual background or activating schemata of the selection in a number of different ways such as delivering questions related to the topic.

The second phase is prediction. Prediction refers to any speculation about the content of the reading material. In order to make a prediction, students use their 
Celtic: A Journal of Culture, English Language Teaching, Literature and Linguistics

Vol. 7, No. 1, June 2020.

E-ISSN: 2621-9158 P-ISSN:2356-0401

http://ejournal.umm.ac.id/index.php/celtic/index

background knowledge about the topic. In this phase the teacher should introduce the topic through delivering question related to the topic to the students.

The third phase is silent guiding. This phase focuses on the process of comprehending the text and finding the information. Students are asked to read the text to seek information, which are related to their predictions, either supporting or not supporting of information. The fourth phase is post reading phase. In this phase, the teacher asked the students to submit the questions.

Next, the second method is reciprocal teaching method. Reciprocal Teaching Method is a method for demonstrating and developing reading comprehension in a group setting. Reciprocal teaching method is an instruction that utilizes four comprehension strategies (predicting, questioning, summarizing, and clarifying) in the form of a dialogue between teachers and students regarding segments of a text (Choo, Eng, \& Ahmad, 2011:141). Reciprocal teaching method was developed to take students through the steps of reading comprehension, so that after repeated practice, the students come to use, on their own, reading strategies that pay off in high rates of comprehension.

Each strategy in the Reciprocal Teaching Method has a crucial role in reading comprehension process. Predicting involves finding clues in the structure and content of a passage that might suggest what will happen next. Clarifying involves discerning when there is a breakdown in comprehension and taking steps to restore meaning. Summarizing is a one or two sentence statement that tells the most important ideas contained in a paragraph or section of text. The summary should contain only the most important ideas and should not include unimportant details. A summary should be in the student's own words. Questions are constructed important information, rather than unimportant details in the text.

Further, Doolittle, Hicks, Triplett, Nicholas, and Yound (2006:107) stated that questioning involves the identification of information, themes, and ideas that are central and important enough to warrant further consideration. The central or important information, themes, or ideas are used to generate questions that are then used as selftests for the reader. Questioning provides a context for exploring the text more deeply and assuring the construction of meaning. Summarizing is the process of identifying the important information, themes, and ideas within a text and integrating these into a clear and concise statement that communicates the essential meaning of the text. Summarizing may be based on a single paragraph, a section of text, or an entire passage. Clarifying involves the identification and clarification of unclear, difficult, or unfamiliar aspects of a text. These aspects may include awkward sentence or passage structure, unfamiliar vocabulary, unclear references, or obscure concepts. Predicting involves combining the reader's prior knowledge, new knowledge from the text, and the text's structure to create hypotheses related to the direction of the text and the author's intent in writing.

In addition, Cooper and Greive (2009:p.46) provide explanations of what students need to do with each strategy in the reciprocal teaching method in learning process namely in questioning the text, students are to concentrate on the main idea and check their immediate level of understanding. In clarifying, while the text is being read, students are to critically evaluate the meaning of unfamiliar words and phrases and to draw upon the collective knowledge of the team members. In addition, they are to seek 
Hamdani, B. (2020). Teaching Reading through Reciprocal Teaching Method. Celtic: A Journal of Culture, English Language Teaching, Literature, \& Linguistics, 7(1), 23-34.

the essence of ideas, main ideas, and themes contained in the text. In summarizing, students are to restate the main ideas and themes in their own words, when summarizing, to ensure that they have fully understood them. In predicting, at critical points in the reading of the text students are to pause, to draw and test inferences from the text about future content.

The directed reading thinking activities and reciprocal teaching method were chosen by researcher as a teaching model in this research in fourth term of English education study program of faculty of tarbiyah of zainul hasan university genggong probolinggo with some judgments. First, there were some problems with the students' reading ability of narrative texts in English teaching and learning process that researcher found in conducting the classroom observation during reading class. The problems are: (1) difficulty to answer some questions in the IELTS Reading testing, (2) difficulty to get ideas of a text or paragraph in the IELTS Reading testing, (3) low motivation to read an English text especially IELTS Reading testing, and (4) no having much opportunity for them to develop the reading comprehension abilities, since most of time English language teaching emphasizes on linguistic knowledge such as grammar points and vocabulary.

Second, the result of IELTS students' reading tests were also unsatisfying, since for understanding of reading a text could be seen from their capability to answer the questions related to the texts. Third, the researcher considers that the reciprocal teaching method is important to be implemented as an instructional model in teaching and learning process at the fourth term of English education study program of faculty of tarbiyah of zainul hasan university genggong Probolinggo in an action to cope with the student's crucial problems in reading comprehension.

The following studies investigated the implementation of reciprocal teaching method and directed reading thinking activities: Suryanto (2009) investigated the improvement of the eleven grade of MAN Muara Tewen, Central Kalimantan. He implemented reciprocal teaching to improve the student's reading comprehension. Though his study, it was found that the student's reading comprehension improved significantly. It could be seen in the result of reading tests. In his preliminary study the mean score of the class was 53.56. The result of reading test in the end of first cycle indicated that the mean score was 58.69. Then, the result of reading test in the end of the second cycle was 72.00. It was also found that both the teacher and the students executed their duties actively and cooperatively in the teaching and learning process through the strategies applied in reciprocal teaching. The teacher gave assistance as needed and the students worked together and helped each other to understand the text provided. The students gave positive reactions towards the implementation of reciprocal teaching.

Zakiya (2008) conducted classroom action research on the implementation of reciprocal teaching method in the teaching of reading comprehension IV at the fourth semester students of State Islamic University of Malang. The study was aimed at improving the students' reading comprehension in three stages of reading activity: prereading, whilst-reading, and post-reading. The result of the study was reciprocal teaching method can effectively improve the students' reading comprehension.

Indrayani (2005) studied on the implementation of reciprocal teaching method for the teaching of English for Specific Purpose (ESP). The study was addressed to the 
Celtic: A Journal of Culture, English Language Teaching, Literature and Linguistics

Vol. 7, No. 1, June 2020.

E-ISSN: 2621-9158 P-ISSN:2356-0401

http://ejournal.umm.ac.id/index.php/celtic/index

first semester students of the Biology Department of the State University of Malang who learnt ESP. The aim of the study was describing the implementation of reciprocal teaching method which involved the teaching steps, the instructional materials, the assessment, and the students' reaction to the method. Through this study, it was found that the students had positive reaction toward the implementation of reciprocal teaching method which they said that they liked the grouping technique of reciprocal method.

Harun (2015) conducted a research entitled the effect of using directed reading thinking activities strategies on reading comprehension ability across students' personality. Its research was a factorial design with post-test design using two groups of second year students of MTs Nasrudin in the academic year 2015/2016. The result of the data analysis showed that the means of reading comprehension of the experimental group using the directed reading thinking activities strategy and control group using conventional strategy was statistically different (Sig. $0.001<$ Sig 0.05). It indicated that directed reading thinking activities was significantly effective in teaching reading comprehension.

To enrich the theory of the method, the researcher conducted the study of the effectiveness of reciprocal teaching method of the teaching reading comprehension at the fourth term of English education study program using IELTS Reading testing.

By considering the description above and going beyond these theoretical justifications, an experimental study seemed to be interesting to be carried out and the Directed Reading Thinking Activities and Reciprocal Teaching Method became the method which were going to be implemented which its effectiveness. Thus, the research entitled "Teaching reading through reciprocal teaching method" was conducted.

Based on the background above the research problem of this study is formulated as do university students taught by using Reciprocal Teaching Method have better reading comprehension than students taught by using Directed Reading Thinking Activity? Concerning the statement of the problem above this research is aimed to find out the effectiveness of the reciprocal teaching method in reading comprehension activities. The researcher assumes that the achievement of students taught by using reciprocal teaching method is different from those taught by using Directed Reading Thinking Activity. The research hypothesis as follow: The students taught by using Reciprocal Teaching Method have better comprehension than the students taught by using Directed Reading Thinking Activity.

The result of this research is expected to give theoretical and practical contributions. Theoretically, the finding of the study is expected to support the theory of the reciprocal teaching method. Besides, it is hoped that this finding will motivate some other researchers to do further studies in proving the effectiveness of this method and it can be a relevant reference for other researchers who want to conduct a research dealing with similar topic. Practically, it provides teachers an alternative strategy to be used in teaching reading to increase the students' reading ability in understanding narrative reading texts.

\section{METHOD}

This study employed a quasi-experimental research, non-randomized control group, pretest-posttest design as recommended by Ary, et.al (2010). The population of the research was fourth term of English education study program in the academic year 
Hamdani, B. (2020). Teaching Reading through Reciprocal Teaching Method. Celtic: A Journal of Culture, English Language Teaching, Literature, \& Linguistics, 7(1), 23-34.

2018-2019. Class A consisting 17 university students was taken as the experimental group, and class B consisting of 17 university students was taken as the control group. The instrument of this research was test, as pre-test and post-test in reading passage on IELTS Reading testing. It was taken from Barron IELTS testing. It consisted of 10 items. The scoring was dichotomies in which correct answer scored 10 and incorrect answer scored 0 . Therefore of 10 items, the maximum score was 100 and minimum score was 0 . The scores of the students' pre-test and post-test were the data sources. The next step that should be done after having collected the data for the research is to analyze the data obtained. Data analysis was aimed at testing the research hypothesis. The result of the pre-test was to know the students' ability in comprehending the texts for both groups before the experiment and to know whether it has been normally distributed and have equal ability being treated. The comparison of the pre-test result was to know the students' ability in comprehending the texts for both groups before the experiment, to know whether it has been normally distributed and have equal ability being treated and to know whether there was significant difference or there was no significant difference. If the comparison of pre-test result showed that there was significant difference, the post-test analysis uses ANCOVA. Meanwhile, if the comparison of pre-test result showed that there was no significant different, the post-test analysis uses independent t-test. Meanwhile, the post-test was to know the students' ability in comprehending the texts after the treatment and to test the nihil hypothesis (Ho) whether it was accepted or rejected. The result of the students' score then was calculated using SPSS 16.

\section{FINDINGS AND DISCUSSION Findings \\ Result of Pretest}

The pre-test is done to know the university students' ability in comprehending the texts for both groups before the experiment. It is to know whether it has been normally distributed and have equal ability before treated. Next, the comparison of the pre test result was to know the students' ability in comprehending the texts for both groups before the experiment. If the comparison of pre test result showed that there was no significant difference, the post test analysis used ANCOVA.

Table 1. Group Statistics

\begin{tabular}{|c|c|c|c|c|c|}
\hline Group Research & & $\mathrm{N}$ & Mean & $\begin{array}{l}\text { Std. } \\
\text { Deviation }\end{array}$ & $\begin{array}{l}\text { Std. Error } \\
\text { Mean }\end{array}$ \\
\hline $\begin{array}{l}\text { Achievement } \\
\text { group }\end{array}$ & $\begin{array}{l}\text { Experiment } \\
\text { Control group }\end{array}$ & $\begin{array}{l}17 \\
17\end{array}$ & $\begin{array}{l}47.6471 \\
42.3529\end{array}$ & $\begin{array}{l}7.52447 \\
10.91410\end{array}$ & $\begin{array}{l}1.82495 \\
2.64706\end{array}$ \\
\hline
\end{tabular}


Celtic: A Journal of Culture, English Language Teaching, Literature and Linguistics

Vol. 7, No. 1, June 2020.

E-ISSN: 2621-9158 P-ISSN:2356-0401

http://ejournal.umm.ac.id/index.php/celtic/index

Table 2. Independent Sample Test

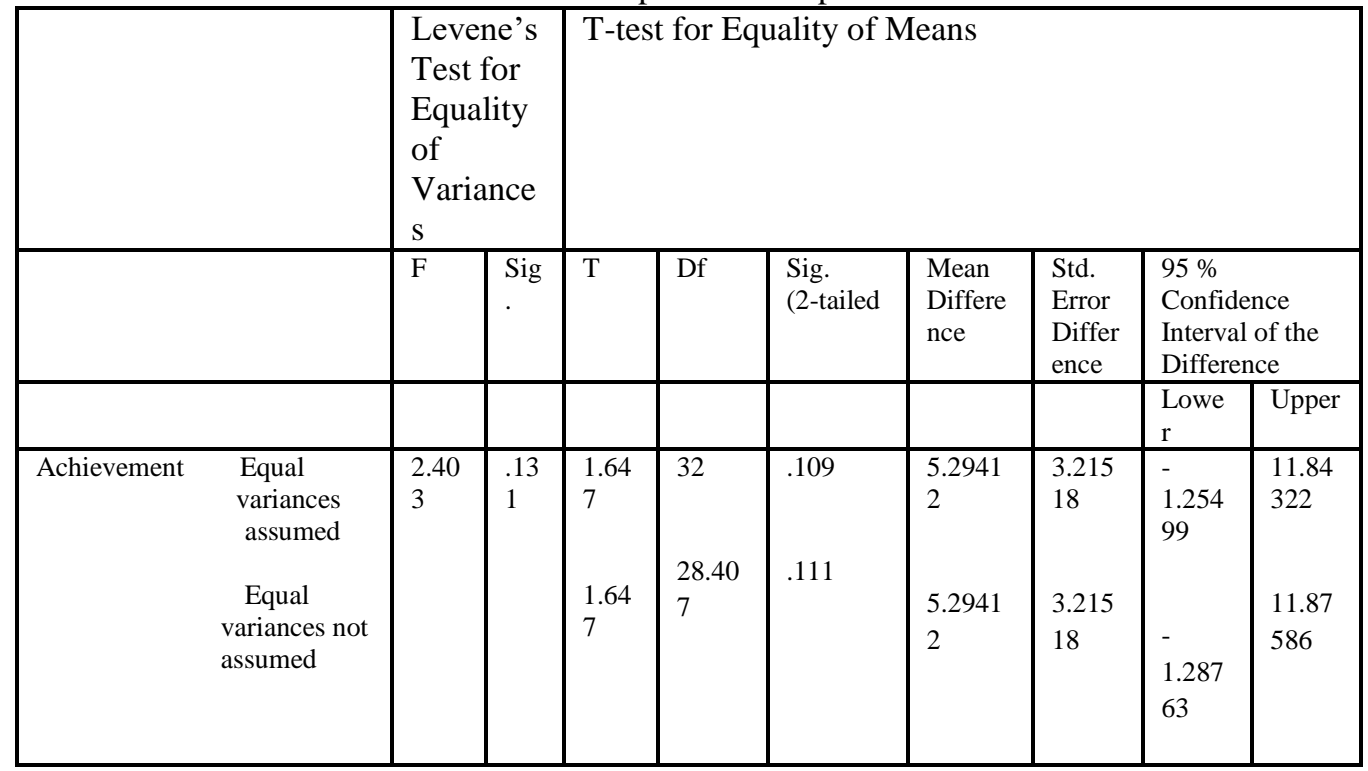

From the table above, it could be seen the summary result of the pre-test for the experimental group and the control group. It showed that the mean score of pre-test of the experimental group was 47.64 and the control group was 42.35. Based on the result of the calculation of pre test from experimental and control group, the p-value was .109 , which is higher than 0.5 (two-tailed). From the data of mean score, it could be stated that there was significant difference between the average scores of experimental group. As a result, the analysis of post test used Independent T-Test.

\section{Result of Posttest Analysis}

It has been described on the previous section that to determine whether the scores obtained by the students in the two groups both experimental and control significant difference, the analysis of independent $t$-test with the critical value of $p<=$ .05 was used. The reason for applying this analysis has also been clearly stated in that chapter. By using computer with the SPSS program, the obtained data were analyzed. It was found that the mean score of the experimental group was 70.5882. Meanwhile, the mean score of the control group was 40.5882

The result of the computation of the total scores of the students on the 10 item test indicated that the p-value was 0.000 , which was lower than 0.05 (two-tailed). It indicated that the post test result of experimental and control groups were significant difference.

Table 3. Group Statistics

\begin{tabular}{|c|c|c|c|c|c|}
\hline Research group & & $\mathrm{N}$ & Mean & $\begin{array}{l}\text { Std. } \\
\text { Deviation }\end{array}$ & $\begin{array}{l}\text { Std. Error } \\
\text { Mean }\end{array}$ \\
\hline Achievement & $\begin{array}{l}\text { Experiment Group } \\
\text { Control Group }\end{array}$ & $\begin{array}{l}17 \\
17 \\
\end{array}$ & $\begin{array}{l}70.5882 \\
40.5882 \\
\end{array}$ & $\begin{array}{l}10.28992 \\
9.66345 \\
\end{array}$ & $\begin{array}{l}2.49567 \\
2.34373 \\
\end{array}$ \\
\hline
\end{tabular}


Hamdani, B. (2020). Teaching Reading through Reciprocal Teaching Method. Celtic: A Journal of Culture, English Language Teaching, Literature, \& Linguistics, 7(1), 23-34.

Table 4. Independent Sample Test

\begin{tabular}{|c|c|c|c|c|c|c|c|c|c|}
\hline & \multicolumn{2}{|c|}{$\begin{array}{l}\text { Levene's } \\
\text { Test for } \\
\text { Equality of } \\
\text { Variances }\end{array}$} & \multicolumn{7}{|c|}{ T-test for Equality of Means } \\
\hline & \multirow[t]{2}{*}{$\mathrm{F}$} & \multirow[t]{2}{*}{$\begin{array}{l}\mathrm{Si} \\
\mathrm{g} .\end{array}$} & \multirow[t]{2}{*}{$\mathrm{T}$} & \multirow[t]{2}{*}{$\overline{\mathrm{Df}}$} & \multirow[t]{2}{*}{$\begin{array}{l}\text { Sig. } \\
\text { (2- } \\
\text { tailed }\end{array}$} & \multirow[t]{2}{*}{$\begin{array}{l}\text { Mean } \\
\text { Differe } \\
\text { nce }\end{array}$} & \multirow{2}{*}{$\begin{array}{l}\text { Std. } \\
\text { Error } \\
\text { Differe } \\
\text { nce }\end{array}$} & \multicolumn{2}{|c|}{$\begin{array}{l}95 \% \text { Confidence } \\
\text { Interval of the } \\
\text { Difference }\end{array}$} \\
\hline & & & & & & & & Lower & Upper \\
\hline $\begin{array}{l}\text { Achievement Equal } \\
\text { varians } \\
\text { assumed }\end{array}$ & .247 & $\begin{array}{l}.6 \\
22\end{array}$ & $\begin{array}{l}8 . \\
76 \\
3\end{array}$ & 32 & .000 & $\begin{array}{l}30.000 \\
00\end{array}$ & $\begin{array}{l}3.4236 \\
6\end{array}$ & $\begin{array}{l}23.026 \\
23\end{array}$ & $\begin{array}{l}36.9737 \\
7\end{array}$ \\
\hline $\begin{array}{l}\text { Equal } \\
\text { variances } \\
\text { not } \\
\text { assumed }\end{array}$ & & & $\begin{array}{l}8 . \\
76 \\
3\end{array}$ & $\begin{array}{l}31.8 \\
75\end{array}$ & .000 & $\begin{array}{l}30.000 \\
00\end{array}$ & $\begin{array}{l}3.4236 \\
6\end{array}$ & $\begin{array}{l}23.025 \\
15\end{array}$ & $\begin{array}{l}36.9748 \\
5\end{array}$ \\
\hline
\end{tabular}

This table showed that the total score obtained by the students in the experimental group was significant difference from that of the control group. This means that reciprocal teaching method is more effective than directed reading thinking activity.

\section{Hypothesis Testing}

The hypothesis of the present study states that there is a significant difference between the learning achievement of the university students taught with reciprocal teaching method in the teaching of English reading comprehension and those who are taught English reading comprehension by using direct reading thinking activities. This finding shows that the alternative hypothesis formulated above is accepted. Thus, reciprocal teaching method gives better contribution to the students' comprehension than of direct reading thinking activities. The implication is that reciprocal teaching method gives positive effects on improving the students' ability in English reading comprehension.

\section{Discussion}

The result of the data analysis presented in previous section showed that the alternative hypothesis that states the students who are taught reading through reciprocal teaching method achieve better in reading comprehension than those who are taught through directed reading thinking activity is accepted. It can be seen from the result of analysis on the post-test, the scores of the experimental group exceed from those of the control group.

The mean score of the experimental group on the reading achievement on the Pre-test is 42.3529 , while in the post-test, the mean score is 70.5882. This showed that the achievement of the experimental group after the treatment is higher, that is 28.2353 points. This finding is in line with Palinscar and Brown (1984) that found in their research that the use of the reciprocal teaching method increased the students' scores on 
Celtic: A Journal of Culture, English Language Teaching, Literature and Linguistics

Vol. 7, No. 1, June 2020.

E-ISSN: 2621-9158 P-ISSN:2356-0401

http://ejournal.umm.ac.id/index.php/celtic/index

reading comprehension. The improvement is reflected in the scores the students' achievement after the implementation of this method.

The improvement on the post test is affected by some reasons. First, the implementation of the reciprocal teaching method is interesting for the students as they never got before. This method needs the students' involvement on every discussion well. Second, the students are more active in discussing the materials because they have their own responsibility in turn so that they try to do their best. Since one group only consists of four students. They apply every method with predicting, clarifying, questioning, and summarizing within their group without feeling shy or frightened. Third, they can share ideas within their group without feeling afraid of making mistake because the members of the group help each other to find the solution. In addition, they can use their background knowledge to share in the discussion. When summarizing, the students are given a model by the teacher first, so that they can do it easily. At last, the consistent way of teaching makes the students get ease to understand the material because they have the clear steps to do it.

After applying this method, the students get ease to make inference from the text. By doing discussion, sharing ideas and having responsibility to lead the discussion for several meetings. It can be seen from the result of the post-test. If it is compared to the result of their pre-test, they get score improvement.

The comprehension activities done in modeling to apply the reciprocal teaching method are included predicting, clarifying, questioning, and summarizing. Predicting occurs when the learners are asked to predict about the content of the information from the topic. They make predictions about what they think will happen in the text. In this stage, the learners activate their background knowledge or experiences to predict what the text will be performed. Their predictions guide them to find out the purpose of reading.

Clarifying has become an important activity where the learners need more explanation about some difficulties found in the text, such as: new vocabulary and unclear referent words. This step trains the learners to monitor their comprehension rather than just reading blindly. Questioning provides a basis for self-testing and interaction with others in the group. It carries the learners into the longer stop in comprehension activity. When learners generate questions, they identify the information that become significant enough to provide the substance for a question. Then they pose the information in their question form and self-test to ascertain that they can indeed answer their own questions.

Summarizing helps the learners to integrate what the text tells about. They will produce their comprehension of reading text by presenting the information they got. The summary may come across sentences, paragraphs, and also the passage as a whole. However, the basic procedure in the reciprocal teaching method is that the learners are generally focused on the sentence and paragraph levels. As they become proficient, they are able to integrate at the paragraph and passage level.

On the contrary, the improvement of the mean score of the students' reading achievement of the control group is low. The result on the pre-test showed that the mean score they achieve is 42.3529 , while on the post-test, they achieve is 40.5882 . The score on the post-test is lower with the score on the pre test. This condition occured because the teacher doesn't apply an interesting appropriate method as the result the students do 
Hamdani, B. (2020). Teaching Reading through Reciprocal Teaching Method. Celtic: A Journal of Culture, English Language Teaching, Literature, \& Linguistics, 7(1), 23-34.

not involve in the discussion well. To sum up, the finding of this research has shown that reciprocal teaching method is more effective than that of directed reading thinking activity on reading comprehension.

Based on the data presented in the previous section, it was found that reciprocal teaching method could bring a good progress on the students' reading comprehension. The involvement of the method toward students' comprehension was evidenced by the students' willingness to share ideas among the group and to help each other in understanding reading texts. Moreover, the anxiety and shyness could also be reduced because the students worked in small groups. When they were asked to report their works to the whole class, the felt confident because their answer was not just from himself alone, but from the whole group.

The implementation of the reciprocal teaching method improves the students' reading ability because of some reasons. First, in predicting, the students predict about the content of the information from the topic. They make prediction about what they think will happen in the text. At this stage, the students activate their background knowledge to predict what the text will be performed. Their predictions guide them to find out unfamiliar words, determine implicit and explicit meaning and coda. Here, the students are asked to get the main topic or idea based on the title before they read the text. When it is done within the group, they are free to do so without feeling shy or afraid to share their ideas.

Next, in clarifying the students need more explanation about some difficult word that found in the text. This step trains the students to monitor their comprehension rather than just reading individually. Within the group, they can do it easily because every member of the group gives their ideas. In addition, In questioning the students have chance to get a basis for interaction with others in the group. When the students generate questions, they identify the information that become significant to provide the answer for a question. Then they pose the information in their question form to ascertain that they can indeed answer their own questions.

The last is summarizing. It helped the students to integrate what $\mathrm{t}$ he text tells about. They will produce their comprehension of reading text by presenting the information they got. The summary comes across sentences, paragraphs, and also the passage as a whole. In conclusion, the finding of this study has shown that reciprocal teaching method is more effective than that of direct reading thinking activity. This finding supported the emerging theory of Palinscar and Brown's (1984) on reciprocal teaching method. Besides, it also supported some previous researches.

\section{CONCLUSION}

From the whole data analysis of the present study, it can be concluded that reciprocal teaching method is effective for the teaching of English reading comprehension. Furthermore, the present study has proved that reciprocal teaching method gives better positive effects upon direct reading thinking activity for developing the students' English reading comprehension skills. The use of reciprocal teaching method in this research was significant difference than Directed Reading Thinking Activities. Therefore, the alternative hypothesis is accepted. It means that reciprocal teaching method is more effective in teaching reading than Directed Reading Thinking Activities. 
Celtic: A Journal of Culture, English Language Teaching, Literature and Linguistics

Vol. 7, No. 1, June 2020.

E-ISSN: 2621-9158 P-ISSN:2356-0401

http://ejournal.umm.ac.id/index.php/celtic/index

Referring to the result of this research, there are suggestions for English Teachers and English lectures, especially those who teach reading. First, they should choose the proper way to teach reading so that the students do not get difficulty in understanding the material. Second, the English teachers and English lectures should take students' involvement more in the teaching learning process. It is done to make the students more active in doing discussion. It is recommended for the future research that this method can be used to investigate any kind of reading texts such as TOEIC Reading test and TOEFL reading test can be done to conduct a research on different skill such as speaking skill.

\section{REFERENCES}

Anderson, N. 1999. Exploring Second Langugae Reading. Canada:Heinle\&Heinle Publishers.

Ary,D.,et al. 2010. Introduction to Research in Education. ( $8^{\text {th }}$ Ed). USA : Wadswort Publishing Company.

Choo, T.O.L.,Eng, K.T, and Ahmad, N. 2011. Effects of Reciprocal Teaching Strategies on Reading Comprehension. The Reading Matrix, Vol. 11 (2). 149-150.

Cooper, T. and Greive, C. 2009. The effectiveness of the methods of Reciprocal Teaching, As applied within the NSW Primary Subject Human Society and its Environment: An Exploratory Study. Education Papers and Journal Articles. Vol. 3 (1), 45-52.

Diah Retno Widowati, Kurniasih Kurniasih. 2018. Critical Reading Skill And Its Implication To Speaking Ability In Multicultural Classroom. A journal of culture, English Language Teaching, Literature and Linguistics (CELTIC). Vol 5, No 2 (2018) DOI :10.22219/celtic.v5i2.7618

Doolittle, P.E.,Hicks, D.,Triplett, C.F.,Nicholas, W.D.,and Young.,C.A. 2006. Reciprocal Teaching for Reading Comprehension in Higher Education: A Stategy for fostering the deeper understandingof texts. International Journal of teaching and learning in Higher Education. Vol. 17 (2), 106-118.

Harris, K.R. and Graham, S. (Eds.).2007. Teaching Reading Comprehension to students with learning difficulties. New York: The Guilford Press.

Harun, Ali. 2015. The effect of using DRTA strategy on reading comprehension across students' personality. Unpublished Thesis:Graduate Program State University of Malang.

Hedgock, J.S \& Ferris, D.R. 2009. Teaching Readers of English: Students, Texts, and Contents. New York : Routledge.

Indrayani, N.,2005. The Implementation of Reciprocal Teaching Method for the Teaching of ESP at the Biology Department of the State University of Malang. Unpublished Thesis Malang:Graduate Program State University of Malang.

Roe, B.,Smith, S.H.,and Burns, P.C.2012. Teaching Reading in Today's Elementary Schools (What's news in Education) 11 th Edition. Wadsword:Cengage Learning.

Saraswati Ayudiah and Sumarsono P. 2014. The use of Mind-mapping to improve students' reading comprehension at SMAN 1 Grati Pasuruan. A journal of 
Hamdani, B. (2020). Teaching Reading through Reciprocal Teaching Method. Celtic: A Journal of Culture, English Language Teaching, Literature, \& Linguistics, 7(1), 23-34.

culture, English Language Teaching, Literature and Linguistics (CELTIC). Vol 1, No 2 (2014): November 2014. DOI: $10.22219 /$ celtic.v1i2.4666

Stahl, K.A. 2008. The effect of three instructional methods on the reading comprehension and content acquisition of Novice Readers. Journal of Literacy Research, 359-393.

Sulistyo, G.H.2011. Reading for Meaning, Theories, Teaching Strategies, and Assessment. Malang: Pustaka Kaiswaran.

Suryanto.,B. 2010. Implementing Recirpocal Teaching Method to Improve The Reading Comprehension Ability of the Eleventh Graders of MAN Muara Teweh, Central Kalimantan. Malang : Unpublished Thesis Graduate School State University of Malang.

Zakiya. L.,F. 2008. Improving Reading Comprehension on the Fourth Semester English Students of Islamic University of Malang Using Reciprocal Teaching. Unpublished Thesis. Malang: State University of Malang in Graduate Program in English Language Education. 